University of Vermont

UVM ScholarWorks

University Libraries Faculty and Staff

Publications

University Libraries

Fall 2007

\title{
The Library and Its Place in Cultural Memory: The Grande Bibliothèque du Québec in the Construction of Social and Cultural Identity
}

Birdie MacLennan

University of Vermont, bmaclenn@uvm.edu

Follow this and additional works at: https://scholarworks.uvm.edu/libfacpub

Part of the French and Francophone Language and Literature Commons, and the Library and Information Science Commons

\section{Recommended Citation}

MacLennan, Birdie, "The Library and Its Place in Cultural Memory: The Grande Bibliothèque du Québec in the Construction of Social and Cultural Identity," Libraries \& the Cultural Record, vol. 42, no. 4 (fall 2007): 349-386.

This Article is brought to you for free and open access by the University Libraries at UVM ScholarWorks. It has been accepted for inclusion in University Libraries Faculty and Staff Publications by an authorized administrator of UVM ScholarWorks. For more information, please contact scholarworks@uvm.edu. 


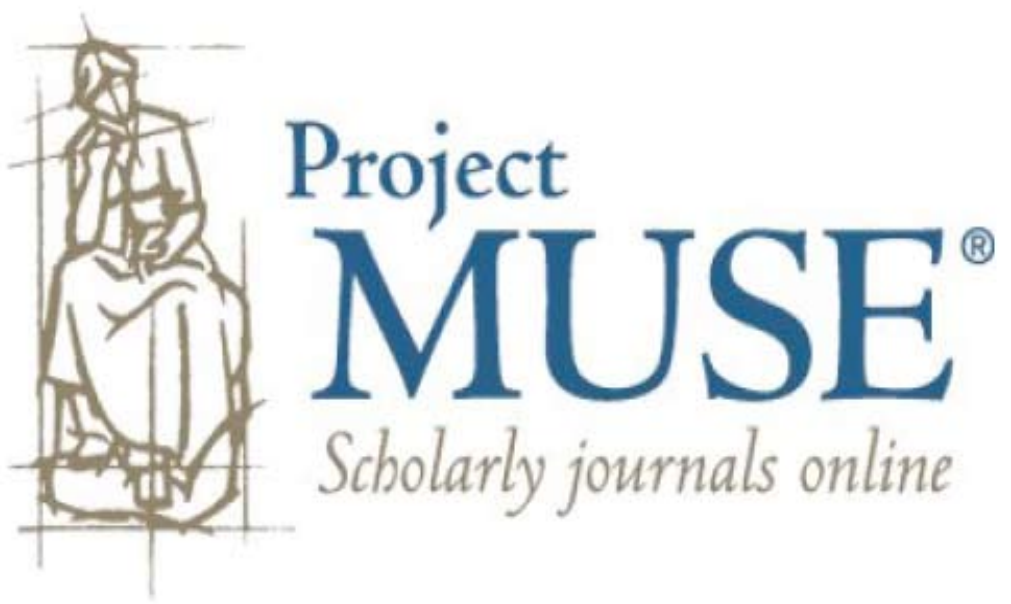




\title{
The Library and Its Place in Cultural Memory: The Grande Bibliothèque du Québec in the Construction of Social and Cultural Identity
}

\author{
Birdie MacLennan
}

The province of Québec, the sole province in Canada where the citizens are a French-language majority, is also the only province with its own national library. The Bibliothèque nationale du Québec and other significant libraries around the world collect and preserve memory in ways that create a context for cultural recall. The first part of this article traces the heated debates that took place in the late nineteenth and early twentieth centuries over the creation of a public or municipal library in Montréal. The second part traces the events leading to the development of the Bibliothèque nationale du Québec and its subsequent merger in 2005 with the Bibliothèque municipale de Montréal to form the Grande Bibliothèque, or "the new national library of Québec." The stages of evolution of the Bibliothèque nationale/Grande Bibliothèque, in parallel with the development of public libraries in Québec, can be viewed as a reflection of the evolution and metamorphosis of society and cultural memory in Québec throughout the nineteenth and twentieth centuries to the present.

One often has the impression that the library is a sort of autobiography in which we can read ourselves and others can read us. The books that we accumulate throughout the years are like the words of a vocabulary that we use; the library represents a kind of syntax for this vocabulary and, in our memory, we construct an ideal and perfect library-perfect because this library contains only that which we wish to remember. That is to say, a book, where the book has had, in our minds, a certain force-not of tomes, not of volumes, but of a few sentences, a few passages or even just a few words sometimes, and this is enough.

-Alberto Manguel, responding to the question, What is a library? in the film La bibliothèque entre deux feux

During the period known as the Révolution tranquille (Quiet Revolution) in the 1960s the Canadian province of Québec affirmed its 
distinctly French social, cultural, and national identity through a series of rapid public reforms. The preservation of the French language and documentary heritage emerged as being of paramount importance-so important that the very first provincial institution to be accorded the status of "national" was the state library. This article examines the pivotal importance of libraries in the development, preservation, and transmission of cultural memory and social identity in Québec, a relatively small enclave of French-speaking inhabitants on a predominantly Englishspeaking North American continent. It begins with an examination of the fabric of Québec's cultural identity, particularly in relation to the development of libraries but also in relation to religious and secular debates that took place in late-nineteenth- and early-twentieth-century Québec, just as the public library movement was taking place in North America. It then focuses on the advent of the Bibliothèque nationale du Québec (BNQ), or the National Library of Québec. The national library's history, evolution, and metamorphosis into an ambitious 90.6million-dollar construction project known as the Grande Bibliothèque du Québec (GBQ) - the national library's merger with the central municipal library of Montréal—can be viewed in parallel to the history, evolution, and metamorphosis of the people of Québec's social identity and cultural memory. Examples drawn from historical and contemporary sources as well as the $\mathrm{BNQ} / \mathrm{GBQ}$ mandate from the provincial government to the people of Québec illustrate ways in which the development of libraries in Québec reflects the historical mores as well as the social and cultural identity of a nation and a people.

\section{Turn-of-the-Century Québec and the Public Library Movement}

Montréal at the beginning of the twentieth century was Canada's industrial, commercial, and transportation center. Lovell's Directory in 1914 described Montréal as the largest city in Canada, the largest city of the British colonies, the ninth city in North America, and the second largest port on the American continent. ${ }^{1}$

During this time Montréal, along with other major cities in North America, was experiencing the height of the Industrial Revolution. Waves of people from the countryside and immigrant populations from different corners of the globe flocked to the cities, seeking a better quality of life and work in the industrial and manufacturing sectors that were flourishing in urban centers. In this same period the United States and Canada experienced the emergence of what has become known as the public library movement-the construction of a significant number of public libraries across the nation. 
The proliferation of public libraries during this time created focus points for the socialization of workers and new immigrants. As industrial workers poured into North America from overseas, they were faced with staggering problems of readjustment. "Many of the nation's public libraries were converted to staging areas for these newcomers to learn the language and the ways of their adopted land." ${ }^{2}$ Libraries became places for new immigrants to adapt and absorb the culture of their new surroundings. There was also sentiment that the democratization of access to knowledge and information provided by libraries was a way to improve the quality of life for the workers as well as to educate them for being integrated, productive members of society.

The proliferation of public libraries at the end of the nineteenth century and the beginning of the twentieth century came about in no small measure because of the efforts of Andrew Carnegie (1835-1919). From 1881 until the time of his death, this Scottish immigrant, who became a wealthy steel magnate and philanthropist, gave millions of dollars in "challenge grants" to aid the construction of public libraries. Carnegie offered to pay for the construction of a public library building for any municipality that would assume responsibility for ongoing annual funding for its operation. By the time he died, his philanthropy had produced some 2,500 new public libraries around the world, including 125 in Canada and over 1,600 in the United States. ${ }^{3}$

Yet as the public library movement flourished in English-speaking regions of the United States and Canada, French-speaking religious and conservative leaders in Québec hesitated to join the ranks. Several prominent Québec scholars, historians, and librarians chronicle a series of heated debates that took place, primarily in the popular press of Québec newspapers at the turn of the late nineteenth and early twentieth centuries. ${ }^{4}$ Much of the debate took place between religious and secular forces over the creation of a free public library in Montréal. This proved to be a struggle over public access to reading, censorship, the Index Librorum Prohibitorum (a list of works prohibited by the Catholic Church, often referred to simply as "the Index"), and what constituted morality, or "de bonnes mœurs." It was essentially a struggle over the control of ideas. ${ }^{5}$ Literary historian Kenneth Landry writes, "In Québec, where the Catholic Church assumed a mission of guiding the citizenry, the challenge of religious authorities was to impede the proliferation of institutions on which the clergy had no control. In their eyes, the organization and direction of libraries should not be entrusted to secular administrators, as was the case in Ontario. For this reason, the Church insisted on [libraries in] a parochial framework." ${ }^{6}$ 
Indeed, as professor Marcel Lajeunesse points out, between 1840 and 1960 there existed in Québec an important network of parish libraries (bibliothèques paroissiales) that were linked to the Québec clergy and that constituted but one of the many church-related social and cultural structures that framed the day-to-day life of French Canadians for more than a century. Lajeunesse and others have pointed out that parish libraries were created as a reaction by the church to popular demand for free public libraries. ${ }^{7}$ The concept of parish libraries entered into Québec in 1844, when the Sulpician religious order launched in Montréal their Oeuvre des bons livres, which, essentially, was the début of the parish library and the precursor to the Bibliothèque Saint-Sulpice. During the same year the Institut canadien de Montréal, one of the first French Canadian literary and cultural associations that defended basic principles of liberal thought and democracy, established a library that over the course of the next several years developed a substantial collection of more than ten thousand volumes and included many titles that were listed in the Index. The Institut canadien ultimately drew the wrath of the church and was condemned by the Montréal bishop, Monseigneur Ignace Bourget. It was forced to close in 1880.

Small parish libraries were administered by volunteers and controlled by the parish priest. One parish library's goals and purpose were described in its catalog:

[The library] must be, at once, a place of moral preservation, intellectual edification and honest recreations[;] . . in other words, its goal is to promote a taste for healthy reading; to combat profanity by opposing dangerous books in favor of books that conform in all matters to religious doctrine; to conserve good morals, in opposing books that corrupt in favor of books of an impeccable morality; to facilitate instruction, by making available to families and individuals readings that are varied, pleasant and solid. ${ }^{8}$

Where did this concern for morality in public reading come from? Historian Michèle Dagenais, in writing about the development of Montréal's public library, speculates that religious and government officials, who maintained close ties with each other, feared to put works that were judged to be frivolous or of a critical nature at the disposition of the people out of a concern that these works were subversive and contrary to the established order. She cites an excerpt from the debate that appeared on March 8, 1907, in La Presse: "It's a question of protecting the souls of our children and guarding the conservation of our national 
faith and morality." She also points out that the principles of public libraries as institutions that are open to all citizens-regardless of their beliefs, their ethnicity, and their social or professional origins-threatened to overturn the established social order, with its ancient system of hierarchies and divisions between different classes and categories of people: "There were many elements of Montréal society opposed to the construction of a public library.... The breach thus created risked compromising the former divisions and hierarchies in encouraging the emergence of institutions and practices of a new kind, that is to say, open to all independent of their beliefs, of their social and professional origins, and of their ethnicity."

Indeed, the debate over a public library in Montréal turned vicious when a law to put a public library in place was officially ratified in $1902 .{ }^{10}$ The discussion over funding for a public library was particularly vitriolic. In 1901, prior to the adoption of the law, the mayor of Montréal, Raymond Préfontaine, had solicited Carnegie's help to construct a municipal library. The request was followed in 1902 by a Carnegie challenge grant offer of $\$ 150,000$ for construction, provided that the city agree to invest $\$ 15,000$ per year to support the project and, notably, to develop its collections. Although the project had support from the liberal constituents, it was vilified by the archbishop of Montréal, Monseigneur Paul Bruchési, and others who shared an ultramontane perspective: "One can predict that the taxpayers of Montréal will have to pay $\$ 15,000$ a year to support an infected establishment one thousand, one hundred thousand times infinitely more dangerous than the most malevolent smallpox virus." ${ }^{11}$ Dagenais pointed out that Mgr. Bruchési feared raising the specter of "intellectual and moral perversion."12

Clearly, the church had a vested interest in the outcome of the debate surrounding the construction of a municipal library and wished to maintain control over what the public could and could not read. Essentially, the ensuing debate was fought around the matter of the content of library materials, that is, the content of the books.

\section{Collection Development at the Heart of the Matter: Good Books, Bad Books}

One day, Brother Léon decided to give us a long diatribe on the topic of books in the Index. . . " All of Victor Hugo, do you understand? All of Victor Hugo is in the Index! He was a writer of dissolute morals with pretensions of being close to God but who practiced more the revolution than the religion! Don't go near 
his books. Satisfy yourselves with a short extract from Travailleurs de la mer that you are asked to analyze in your French class. Don't read his poetry! Don't read his novels! His works are pernicious!" -Michel Tremblay, Un ange cornu avec des ailes de tôle

Collection development was at the heart of the matter. Most of the popular authors of the day, including many writers whose works have now become classics (Hugo, Balzac, Dumas father and son, Lamartine, Voltaire, Sand, Zola), were prohibited by Rome in the Index and thus by religious authorities in Montréal who shared the ultramontane perspective of the church. One of the central areas of tension around the construction of a municipal library revolved around what types of books the library would contain and the matter of opposition to mauvais livres, or bad or dangerous books. The church was adamant about the need for censorship to assure that only "bons livres", that is, "good books," or books "d'une irréprochable moralité"-books that upheld the moral values of the church-should be made available. Most literary works, particularly novels, were excluded from the category of "bons livres" since they were prohibited in the Index. The idea of a library that gave unlimited access to novels-imaginative fictional works-was considered dangerous.

This perspective was summarized by Aegidius Fauteux, a young journalist who would later become the director of the Bibliothèque SaintSulpice, when he wrote under a pseudonym in December 1901 to the newspaper La Patrie an eloquent plea for a public library in Montréal: "Without a doubt, there are [in Montréal] some very worthy-and even considerable-libraries that are worth taking note of, such as ... the Cabinet de Lecture, the Fraser Institute, and the McGill University Library. Yet they belong to institutions and are not accessible to all, or they are of a special kind and don't yet respond to all needs." Yet in the same article he cautioned against the danger: "The popular library can be very useful, but by the fact that it is so often dangerous when it is not Christian, one must hesitate before giving it to the people or, at least, submit it to the control of the priests or spiritual shepherds." 13

In order to avoid the inherent dangers of a "popular" public library, Fauteux recommended a research library for the purposes of study and consultation, "always under the strict but wide-ranging vigilance" of church authorities but with enough flexibility to enable users to work at ease with adequate and sufficient resources to meet their needs. ${ }^{14}$ Fauteux advocated above all for a public library that would serve as an effective tool to advance the intellectual progress of French Canada, yet, having been raised as a student of the Sulpicians, he could not 


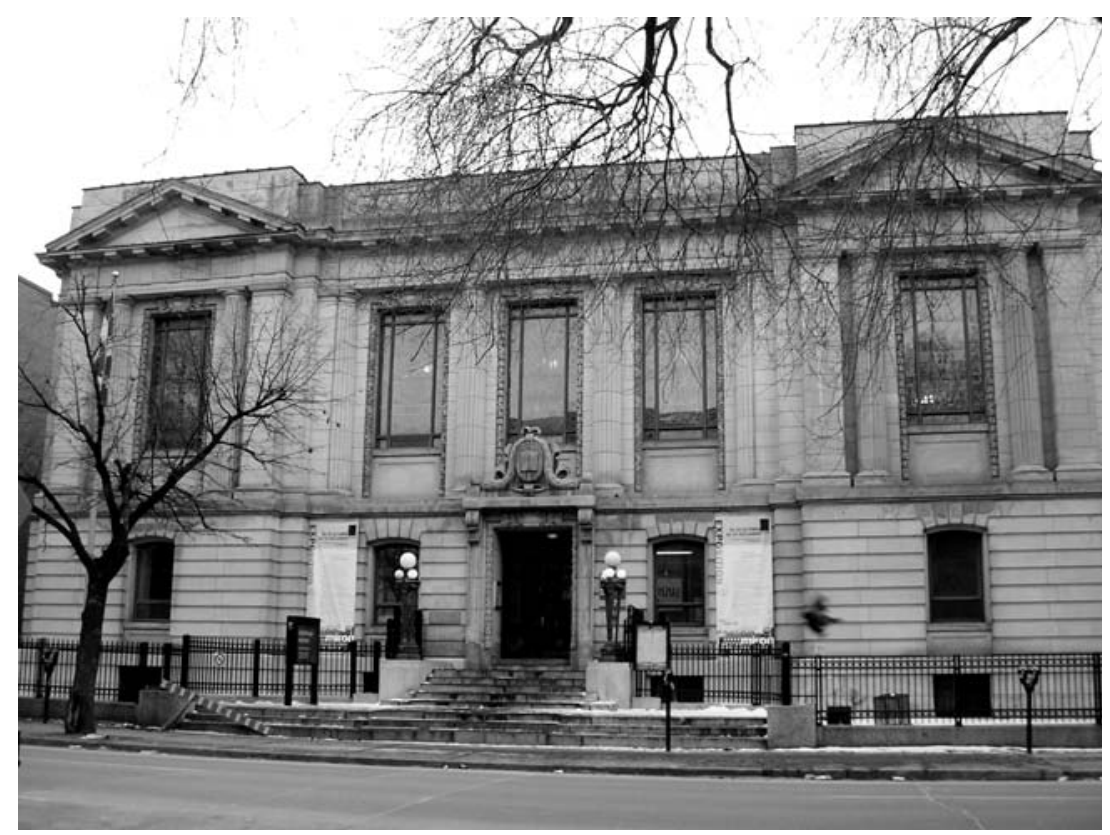

Figure 1. The Bibliothèque Saint-Sulpice, rue Saint-Denis, Montréal, in 2004. Opened in 1915, it became a publicly funded library in 1944 and the first Bibliothèque nationale du Québec (BNQ) in 1967-the first institution in Québec province given the "national" designation. Photo by the author.

separate the idea of a public library from an inherent belief in the need for monitoring closely its collections, which essentially amounted to submitting it to the church's censorship. ${ }^{15}$

The fact that the Carnegie offer was contingent on the ongoing development of library collections essentially stirred such a controversy that in 1904, after three years of bitter debate, the project was officially abandoned. ${ }^{16}$ Nonetheless, the public debate gave way to an important outcome: the idea of a public library was solidified by ratification of the 1902 municipal law. There was no turning back. The municipal library of Montréal had been founded. In 1903 the city council accepted the offer of the Société Saint-Jean-Baptiste to administer a modest library, the Bibliothèque technique de Montréal, which was established in the city's center at the édifice du Monument national, rue Saint-Laurent, the headquarters of the Société Saint-Jean-Baptiste. Thus, the municipal library for the city of Montréal made its début as a scientific and technical or "industrial" library. ${ }^{17}$ Essentially, the city rented in the Monument national building a one-room space for the library. ${ }^{18}$ The small library 


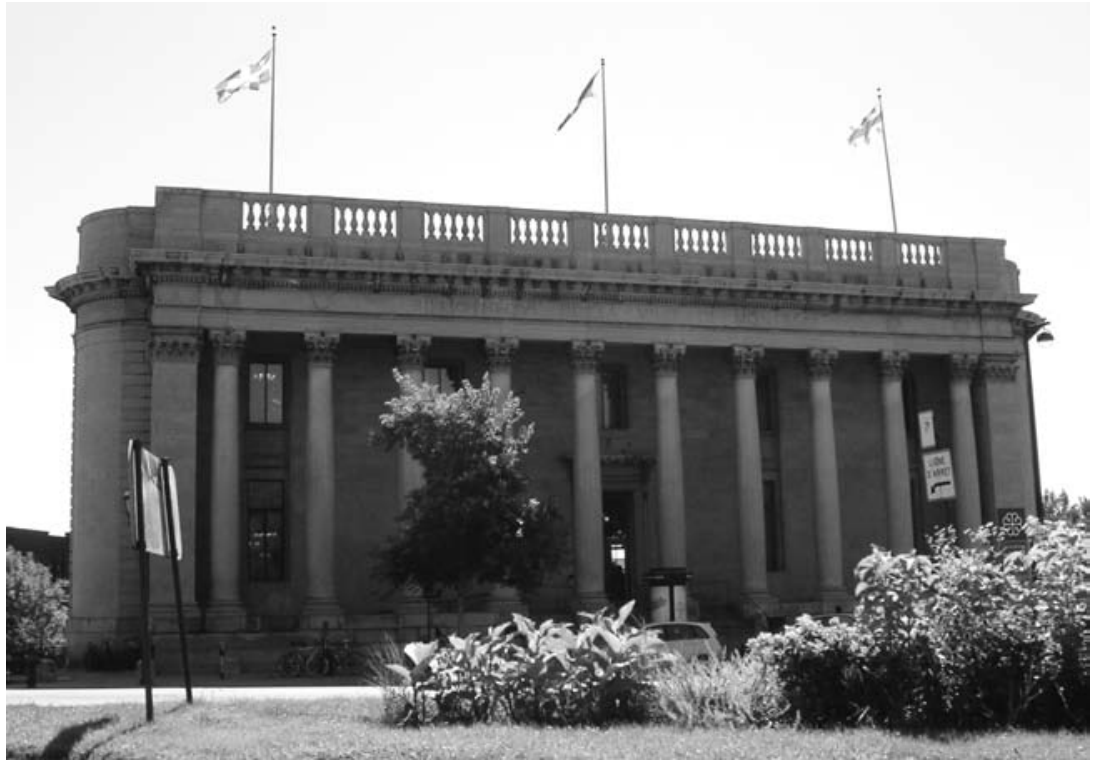

Figure 2. The Bibliothèque de la ville de Montréal, rue Sherbrooke East, Montréal, in 2004. The first publicly funded and secular library in Québec, it opened May 13, 1917. Photo by the author.

was used regularly and assiduously by the population, and, within two years, the question again emerged of the need to construct a library with adequate space to accommodate public demand. A new debate ensued concerning the location and pertinence of constructing a larger library, larger and more accommodating than the modest locale at the Monument national.

\section{Two Libraries amidst Church and State}

Within the course of the next ten to fifteen years two public libraries would emerge. The Bibliothèque Saint-Sulpice was inaugurated on September 12, 1915, on the rue Saint-Denis as a public research library, privately funded by the Sulpician religious order. The Bibliothèque de la ville de Montréal, the first truly municipal library supported by public funds, was subsequently inaugurated on May 13, 1917, on the rue Sherbrooke East. While both libraries were free and open to all, the inauguration of the municipal library marks a particularly important moment in Québec history. It was the first library oriented toward francophones that was both secular and truly public in the sense that 
it was financed entirely by public funds. Otherwise, the two libraries had several important elements in common. Both were located in Montréal's downtown Latin Quarter within a mile of each other. Both were designed as neoclassical monumental structures in the style of the École des Beaux-Arts. Indeed, both construction projects were presided over by the same architect, Montréal native Eugène Payette.

Yet the questions imposed by the church of censorship, morality, and how library collections should be developed would continue to be omnipresent for decades to come. Lajeunesse points out that at the first public conference offered by the Bibliothèque Saint-Sulpice on October 26, 1915, Aegidius Fauteux, conservator of the library, gave a presentation entitled "Règlement d'une bibliothèque catholique" (Administration of a Catholic Library). Fauteux addressed the moral responsibility of the librarian in following regulations prescribed by the church and particularly in using the Index to guide decisions about materials that might be problematical or dangerous. "Why would anyone find it strange that, as a Catholic library, we follow the instructions of the Church? It is the opposite that would be strange. There is, in fact, nothing wiser than the legislation of the Index." 19

Fauteux documented in some detail the restrictions that were imposed on a Catholic library and the attention given to separating volumes into three distinct categories: prohibited books, dangerous books, and innocuous books:

In all Catholic libraries . . . the books are divided into three categories: (1) prohibited books that are lent only to a restricted number of people having the character to read them; (2) books merely dangerous that one can lend with impunity to several people by taking into account their age, their education, or their temperament but that it would be imprudent to trust to a great number of other people who are less equipped or less mature; (3) finally, the inoffensive or innocuous books that can be read by all, or nearly all, people..$^{20}$

Jean-René Lassonde, librarian and historian, has noted that the nuances of this type of censorship were transposed in the card catalog of the Bibliothèque Saint-Sulpice, as evidenced by the letter $\mathrm{R}$ stamped in purple ink in the left-hand corner of the cards for certain catalog entries. The more Rs on the card, the more dangerous the book was considered to faith and morality. For example, R signaled attention (vigilance), RR, réserve (restriction), and RRR, grande attention (dangerous or forbidden). ${ }^{21}$ 
Although Fauteux professed that "it is the novels that constitute the principal danger of a library," he also recognized that this was the most popular form of reading among the library's clientele. ${ }^{22}$ Between September 1915 and April 1916, the first six months or so of the library's operations, the average use of fiction in the Main Reading Room was 50 percent, while in the Department of Circulation the figure had reached 80 percent. ${ }^{23}$ Library users evidently had a preference for works that were considered dangerous.

Over time, Fauteux obtained special permission from Rome that the Bibliothèque Saint-Sulpice be exempt from the prohibitions of the Index. In his negotiations with church authorities on this matter he invoked the looming specter of the construction project for the municipal library: "There are preparations under way in Montréal for a municipal library that cannot offer the same guarantees that ours offers. ... [This special dispensation] is a liberty that we need more than ever if we don't want the new municipal library to take our readers from us while offering a lesser degree of security." ${ }^{4}$ This correspondence, in October 1915 and February 1916, shortly after the Bibliothèque SaintSulpice had opened, shows that the Sulpicians were keenly aware that they were competing with plans for the development of the municipal library and, in fact, had concerns about losing patrons to an institution that offered a form of open access that was not regulated by Rome or the Index. Fauteux persevered and in April 1916 received a favorable response from Rome. ${ }^{25}$

\section{Libraries, Censorship, and the Grande noirceur}

The Catholic Church exercised enormous influence on public reading. This influence permeated the social, educational, and cultural fabric of Québec society and extended into the administrative activities of the municipal library before, during, and after the foundation of the Bibliothèque Saint-Sulpice. When the municipal library was initially founded in 1902 and the city council went about the task of establishing a library commission to oversee its administration, two of the city councilors proposed that the library be subjected to a censorship committee composed of "three censors, one named by the city council, one being the principal of McGill University, and one being the vice rector of the University Laval at Montreal." ${ }^{26}$ Yet in spite of this proposal the city regulation stipulated simply that "the free public library of Montréal will be administered by a special commission composed of a maximum number of nine councilors chosen by the city council." 27 


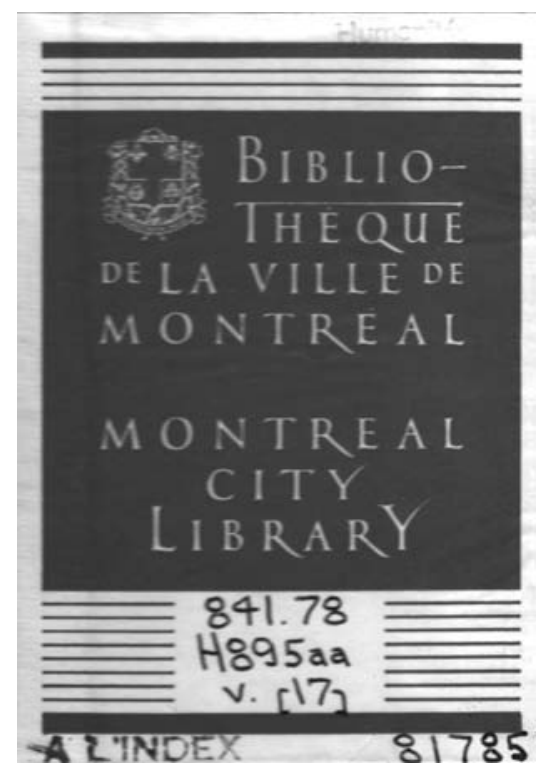

Figure 3. Volumes of Victor Hugo's Notre Dame de Paris in the Bibliothèque municipale were labeled with this bookplate indicating censorship. "À L'INDEX" meant the classic work was on the Catholic Church's Index Librorum Prohibitorum (list of forbidden books). Church censorship of public library books continued in Quebéc province until 1966. Ville de Montréal, Collection de la Bibliothèque centrale.

Nonetheless, one of the commission's roles was to monitor the authorization of the acquisition of books chosen by the librarian. The Bibliothèque municipale was subject to an enormous amount of pressure to stay within the confines of its original mandate as a technical library in collecting scientific, industrial, and technical materials. Because the church remained intransigent on matters of censorship, the Bibliothèque municipale avoided collecting literary works during its first few years of operation so that the library would not become a target for the clergy. Yet, little by little, library patrons began to inquire about literature. The chief librarian, Éva Circé-Coté, responding to their requests, approached the library commission and in November 1905 was granted authorization to purchase French literary classics. ${ }^{28}$

The subtle changes in the Bibliothèque municipale's collection did not pass unnoticed by church authorities. In February 1907, as he learned of the library's growing literary and historical collection, Mgr. Bruchési decided to intervene. In a letter to the library commission he wrote, "I believe that I am filling an obligation in being vigilant that, in 
a library open to all, there be no books that damage the souls that I've been entrusted to guard." Dagenais has further noted that this letter, conserved in the archives of the Archdiocese of Montréal, is accompanied by a list of titles deemed dangerous, including works by Rousseau, Voltaire, Sand, Balzac, Michelet, and others that treat "mysticism and madness" or "the sexual question exposed to cultivated adults [who are deemed to be] completely rational." ${ }^{29}$ The letter succeeded in invoking a need to tightly monitor the reading of the workers and the petits gens (commoners; literally, "little people") who frequented the library. It also led to an inquest into library operations that resulted in tighter controls on the library's collections. ${ }^{30}$

Just as the Bibliothèque Saint-Sulpice had a system of censorship notation in its card catalog, the municipal library had a method of categorizing books according to the perceived levels of risk or danger to faith and morality. The judgment rendered on individual works frequently appeared in the lower left-hand corner of the ex-libris in the book. For example, use of the letter $\mathrm{O}$-or multiple Os-was particularly common. The greater the number of Os (the maximum was four), the more dangerous the book was considered to faith and morality. For example, Le passage de l'Aisne by Émile Clermont, an account of a battle during World War I, was labeled O. La peinture au musée de Vienne by Claude Roger-Marx was designated OO.

Other notations, perhaps more self-evident, that were employed included "défendu" (forbidden), "à l'Index" (listed in the Index), or R for books that were monitored at the reserve desk. Others carried special seals: "Bureau de la censure des théâtres, Propagande des bons livres," "Bureau de la vérité," or "Service de la Police, Bibliothèque théâtrale." Thus, Victor Hugo's Notre Dame de Paris was "à l'Index," The Works of Oscar Wilde was défendu. Le député Leveau by French Academy author Jules Lemaître was slapped with the seal "Service de la Police, Bibliothèque théâtrale, censeur." According to Jean-François Chartrand, curator of an exhibition marking the centenary of the Montreal municipal library, this form of censorship prevailed until the 1960s. ${ }^{31}$

Censorship was not limited to libraries. The church's influence was pervasive throughout the publishing and bookselling trades as well as the educational sector for well over a century in a period of conservatism often referred to as the Grande noirceur (Great Darkness). The church would be challenged by such dissidents as writer and professor of literature Gérard Bessette in his 1960 novel Le libraire and by bookseller and publisher Paul Michaud, founder of the Institut littéraire du Québec, but the Index and its prohibitions were not lifted until $1966 .{ }^{32}$ 


\section{Toward the Separation of Church and State: The Révolution tranquille}

From a purely cultural vantage point, the development of two public libraries where there had previously been none was a great boon to the city. The front page of the March 3, 1915, issue of La Presse boasted of the Bibliothèque Saint-Sulpice as "a book palace in marble." City administrators were proud to have at last a monument worthy of the Canadian metropolis that was Montréal. In years to come they could even boast of having constructed two cultural monuments in less than a decade. ${ }^{33}$

Nonetheless, in the development of these two libraries a division had been created in the cultural landscape of Québec. With each step the clergy took to suppress free access to books and reading-in effect, to inhibit the free flow of thought and ideas-there came, on the one hand, submission and acquiescence and, on the other, manifestations of quiet but steadfast resistance to the church's authority, as reflected in the work of Bessette and Michaud.

Perhaps the most important element in the debate over a municipal library in Montréal was that it raised the issue of the need for separation of church and state. The very existence of a municipal library and all that it represented (i.e., free access to information and inquiry through the written word) was living testament, a monument, so to speak, to the need for emancipation from church repression. Yet, as the church continued to intervene in the cultural and educational landscape of modern, contemporary society for years to come, writers in increasing numbers would call the church's actions into question, eliciting a widespread movement toward the laicization of culture, society, and education for the French-speaking people of Québec.

This movement culminated in the 1960s with the advent of the Révolution tranquille, when much of the social and cultural doctrine imposed by the church on education and cultural values was rejected in favor of a growing tide of modernization and nationalist sentiment. The Bibliothèque Saint-Sulpice and the Bibliothèque municipale continued to exist side by side for nearly a century. The unification of their respective roles into a single cultural institution would not be fully realized until the twenty-first century, with the advent of the Grande Bibliothèque.

\section{Bibliothèque Saint-Sulpice: The Wings of Icarus and the Ashes of the Phoenix}

As Icarus had wings to soar, the Bibliothèque Saint-Sulpice, from its beginnings in 1912 through the next fifteen years or so, had the 
leadership and resources to thrive as a vibrant cultural center with a growing collection as well as lectures, cultural programming, and a series of expositions in the heart of Montréal's Latin Quarter. Yet, as Icarus found his downfall in the sun, the Bibliothèque Saint-Sulpice would, toward the end of the 1920s, find its wings beginning to melt in the gradual but persistent decline of collection development and cultural activities. The Sulpicians, as sole financial supporters of the library, were profoundly affected by the economic climate that ensued and culminated in the Great Depression, or Crise économique. As their financial resources diminished, so did the collection development and cultural activities of the Bibliothèque Saint-Sulpice. In spite of the best efforts of the library's director, Aegidius Fauteux, and of the Amis de la Bibliothèque Saint-Sulpice, the Friends of the Library, to rally support for the library, the Sulpicians, ridden with debt, were left with little recourse but to close the doors of the library to the public in July 1931. ${ }^{34}$ Fauteux would write, "Better a quick but honorable ending than a slow but certain decline." $" 35$

Fauteux resigned his post as conservator and in June 1932 began working at the municipal library, where he would assume a leadership role as chief librarian until $1941 .{ }^{36}$ In 1937 Fauteux was one of the original founders, with Marie-Claire Daveluy, of the École de bibliothécaires at the University of Montréal, the first francophone library school in North America and the forerunner of the university's present-day École de bibliothéconomie et des sciences de l'information (EBSI) ${ }^{37}$

The Bibliothèque Saint-Sulpice languished for more than a decade as though in a state of abeyance awaiting a renaissance, like the ashes of the phoenix, waiting to be reborn. After its official closure to the public in July 1931, the building and its collection were preserved with minimal staffing. In May 1937 the Sulpicians withdrew and the library closed definitively.

In 1939 the government, with renewed interest in opening the library, authorized an inventory under the direction of René Garneau. Garneau's report qualified the library as "the most important French library in the province after the parliamentary library" and an "important intellectual center." 38 On March 13, 1941, the library was officially acquired by the Québec government for $\$ 742,000$, the amount of tax dollars owed by the Sulpicians to the city of Montréal. ${ }^{39}$ Jean-Marie Nadeau assumed the role of director in 1942 and began the work of preparing the library's reopening. On January 16, 1944, after thirteen years of uncertainty, the Bibliothèque Saint-Sulpice was reopened to the public under the auspices of the Department of the Provincial Secretary. 
In 1961 the reporting structure of the library was shifted to the newly created Ministry of Cultural Affairs. Deputy Minister Guy Frégault played a key role in repatriating a young and dynamic librarian, Georges Cartier, to Québec. Cartier, who had been directing library services for UNESCO in France, was engaged in 1964 as chief conservator of the Bibliothèque Saint-Sulpice. In addition to being a man of letters, Cartier was the first professional librarian to direct the Bibliothèque Saint-Sulpice.$^{40}$ Cartier's mandate, as described by Roland Auger, formerly Cartier's adjunct conservator, was to "rekindle the glow of the embers and to guide the specific destiny for this governmental service." ${ }^{11}$

Cartier was known for his dynamic personality, remarkable sense of organization, and "savoir-faire." ${ }^{42}$ Within the first two years of his appointment Cartier succeeded in tripling both the library's budget and the number of its employees. ${ }^{43}$ As the collections once again began to grow and multiply, so did cultural activities such as lectures and exhibitions. The library was also renovated. The external stonework was cleaned and revitalized, the interior walls were repainted, the stainedglass windows were cleaned, the oak woodwork was refinished, and the ventilation, heating, and lighting systems were brought up to date. The minister of cultural affairs proclaimed, "The Bibliothèque Saint-Sulpice has recovered the spark of its original splendor." ${ }^{44}$ Under Cartier's direction, the Bibliothèque Saint-Sulpice was indeed the proverbial phoenix rising out of its ashes to its past, present, and future state of splendor, once again a dynamic library and an information and cultural center in the heart of downtown Montréal.

\section{From Bibliothèque Saint-Sulpice to Bibliothèque d'état to Bibliothèque nationale}

In October 1964, shortly after Cartier was named chief conservator of the Bibliothèque Saint-Sulpice, the Association canadienne des bibliothécaires de langue française formed a committee to study the transformation of the Bibliothèque Saint-Sulpice into a provincial or state library. The work of this committee, presided over by Cartier, would be particularly important in charting the future direction of the library as well as its status as a government institution. In September 1965 the committee issued a report that would form the framework for the transformation of the Bibliothèque Saint-Sulpice into-after various transformations in appellation-a national library. ${ }^{45}$

Although the study was framed in the context of a provincial or state library, modeled perhaps after American state libraries, the deputy 
minister of cultural affairs had asked Cartier to furnish a definition of a national library, which Cartier did on December 31, $1964 .{ }^{46}$ Indeed, the committee's study included elements concerning the "the role of a national library" and "distinct aspects of Québec; relations of the Provincial Library [of Québec] with the National Library [of Canada] in Ottawa." Included among the committee's recommendations were that "the State Library of Québec be created [and] that the State Library of Québec, designated as such, be the Bibliothèque Saint-Sulpice." ${ }^{47}$

The report clearly had implications for the idea of a research institution in a national context with a particular function to preserve Frenchlanguage documentary heritage for all of Canada: "Collect and conserve in its original form the totality of the production of printed French-language materials in Canada and of the foreign production [of printed materials] relative to French Canada; to acquire and conserve a vast collection of Canadiana in diverse disciplines, all documentation useful to research." 48 The committee's report was received favorably. At about the same time the report was made public, a letter from Patrick Allen, secretary of the committee of the Société Saint-Jean-Baptiste de Montréal, which had been charged with presenting testimony before the Royal Commission of Inquiry on Education in the Province of Québec (more commonly known as the Commission Parent), informed Cartier that the Société "urgently recommends that a National Library of Québec be created." ${ }^{9}$

In November 1965 Pierre Laporte, minister of cultural affairs, conferred the title of Bibliothèque d'état (State Library) on the Bibliothèque Saint-Sulpice in his Livre blanc (White Book) on cultural policy. Deputy minister Frégault would note in his memoir that there was a preference for the name Bibliothèque nationale; however, out of respect for Canadian federalism, jurists who were charged with drafting laws were opposed to the term. ${ }^{50}$ There is little doubt that consideration of the existence of the National Library of Canada, founded in Ottawa in 1953 , was at least part of the reason why the project to transform the Bibliothèque Saint-Sulpice into a governmental institution was initially framed in the context of a state or provincial library.

The period from 1964 to 1967 was clearly one of major transformation, marked by a phenomenal growth of the Bibliothèque SaintSulpice in terms of budget, staff, collections, cultural programs, and library patrons. In a memorandum addressed to the deputy minister of cultural affairs on October 6, 1965, Cartier wrote, "One of the major problems that I've encountered since the beginning of my appointment [as conservator in February 1964] . . . is the lack of available space at the Bibliothèque Saint-Sulpice, both for personnel and collections." 51 
Indeed, from 1964 to 1967 the number of personnel grew from twentyfour to sixty-five and the operating budget increased from $\$ 133,000$ to $\$ 400,000.5^{52}$ The need for new space had become imperative.

The government was responsive to the growing need and in 1966 acquired the building that had been occupied by the Jewish Library of Montréal, thus procuring an additional 10,000 square feet in an annex that would house newspaper and periodical collections and government documents as well as technical services operations. A reading room with a view of Mont-Royal would accommodate about sixty patrons. ${ }^{53}$ The Annexe Aegidius-Fauteux, named in honor of the first conservator of the Bibliothèque Saint-Sulpice, was inaugurated on November 14, 1966. At the opening ceremony the new minister of cultural affairs, Jean-Noël Tremblay, announced the library's new status: "It seems necessary to emphasize that in our minds the Bibliothèque Saint-Sulpice is, from now on, our state library." ${ }^{54}$

Because the framework for the Bibliothèque Saint-Sulpice's function as a national library was already in place, the appellation of "state" became synonymous with "national." On December 7, 1966, the ministry announced the transformation of the Bibliothèque Saint-Sulpice into the Bibliothèque nationale du Québec. ${ }^{55}$ On August 12, 1967, the Québec Legislative Assembly voted unanimously for Law 91, which created the BNQ under the auspices of the Ministry of Cultural Affairs.

\section{The Context for a National Library in Québec}

One might ask the question, Why a national library in Québec? After all, the National Library of Canada had been established in 1953 in the federal capital of Ottawa. What events and changes in the political and social climate led to the formation of a national library?

When the national library was created in 1967, Québec was at the height of the Révolution tranquille, a period of collective awakening that began in the 1960s following the end of the Grande noirceur and the long reign of the conservative government of Maurice Duplessis. The "revolution" was characterized by sweeping social, educational, and cultural reforms for French Canadians, who affirmed their identity as Québécois. They sought a new social vision encompassing a national identity that affirmed their language and culture while propelling them into the modern epoch. Québec secularized its schools and more than doubled its provincial budget between 1960 and 1967 .

When the Liberal government of Jean Lesage created the Ministry of Cultural Affairs in 1961, Lesage affirmed that "the government has 
the intention of making the province of Québec a center for the transmission of French culture in America. The French culture constitutes a set of values that enriches all of Canada. We believe that the creation of a Ministry of Cultural Affairs is a vital necessity, especially at the moment when the collective population of Québec has awakened to the contribution that it brings to the blossoming of our national life." 56 The new ministry unified service functions for archives, libraries, and museums; the Conservatory of Music and Dramatic Arts; departments charged with aid and encouragement to literary, scientific, and artistic endeavors; and a new department, Canada français outre-frontières (French Canada beyond Borders).

When Deputy Minister of Cultural Affairs Guy Frégault called upon Georges Cartier to take direction of the Bibliothèque Saint-Sulpice in 1964, the partnership between government and library administration was thus assured. This boded well for the institution in terms of governmental and broad-based tax support as well as recognition of the library as a cultural instrument for preserving and promoting, with newfound pride, the French-language heritage of Québec.

\section{Preservation of French Identity: Charles de Gaulle's Influence}

The year 1967 was particularly significant in the cultural landscape of Québec. Montréal hosted the Universal Exposition (Expo 67), which opened in April, and the country celebrated the centenary of the Canadian federation. French president Charles de Gaulle visited Canada that summer, stopping first in Québec, where he had, naturally, a special affinity for the French-speaking population and where he wished to bolster popular morale by reaffirming the historical connection between France and Canada. His initial plan was to visit Québec Province and the Universal Exposition and subsequently continue on to Ottawa to meet with federal officials.

After his visit to Québec City on July 23 he set out the next day along the Chemin du Roi (Route 138) toward Montréal. He made several stops in towns and cities along the way, giving speeches and encouraging the spirit of French pride and nationalism. De Gaulle, known as the liberator of France from the German occupation during World War II, sparked a kind of nationalist liberation sentiment in Québec that would have repercussions for decades to come. Indeed, he was greeted in Québec as a liberator, with signs along the route that read "France libre!" and "Québec libre!" Such sentiments served to draw parallels between his liberation of France and the liberation movement that was sweeping Québec during the Révolution tranquille. De Gaulle responded accordingly. Key phrases 


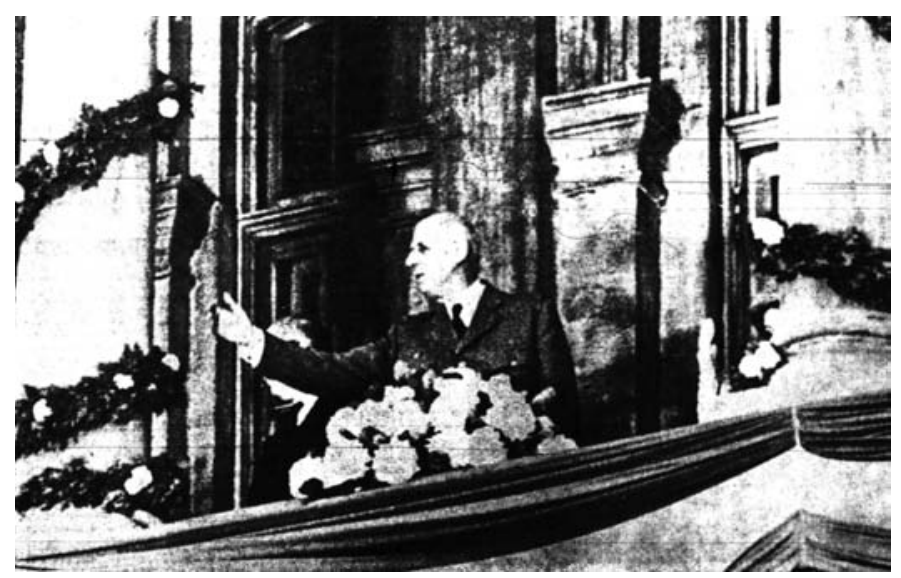

Figure 4. Charles de Gaulle proclaims "Vive le Québec libre!" from the balcony of Montréal's city hall, July 24, 1967. His words inspired a new pride in the French language and the distinct cultural heritage of Québec. La Patrie, July 30, 1967, p.1, from collection of the Bibliothèque et Archives nationales du Quebec.

from the speeches he made to the throngs of people that welcomed him along his journey to Montréal on July 24, 1967, included:

In Sainte-Anne: "Vous serez ce que vous voulez être" (You will be what you want to be).

In Trois-Rivières: "Le Québec devient maître de lui-même pour le bien du Canada tout entier" (Québec becomes its own master for the good of all of Canada).

In Louiseville: "La France entend contribuer aux transformations matérielles et morales du Québec" (France intends to contribute to the material and moral transformations of Québec).

In Berthier: "Vous prenez en mains vos destinées pacifiquement et par les moyens modernes" (You take your destiny in hand peacefully and by modern means).

In Repentigny: "La collaboration dans les deux sens va aller en se développant" (Two-way collaboration will develop). ${ }^{57}$

The most memorable moment of the day was when de Gaulle reached Montréal and was welcomed by the mayor of the city, Jean Drapeau. On the balcony of city hall de Gaulle, greeted by a throng of cheering masses and clearly building on the events of the day, gave an unscheduled speech that ended with the words, "Vive Montréal! Vive le Québec! Vive le Québec libre! Vive le Canada français et vive la France!" 
The words "Vive le Québec libre!" set off a diplomatic furor within the federal government in Ottawa. Canadian prime minister Lester Pearson considered the speech as unacceptable interference in Canada's internal affairs. On the following day, July 25, de Gaulle visited the French Pavilion at the Universal Exposition. Although he was scheduled to continue on to Ottawa to meet with federal officials, his speech had stirred such a controversy with the federal government that de Gaulle cut short his visit. He departed for France on July 26, abandoning the trip to Ottawa. ${ }^{58}$

De Gaulle's visit inspired among the general population of Québec new pride and confidence in the French identity, language, and cultural heritage distinct to North America while encouraging a movement to protect and preserve this legacy for generations to come. He reinforced Canada's connection to France and France's connection to Canada-and particularly to Québec. As a result of his visit, closer relations developed between France and Québec in the domains of education, science, and culture. At the federal level, the government in Ottawa would also pass legislation giving French speakers more recognition and prominence in Canadian society. De Gaulle's goal in helping the Québécois gain recognition of their special standing within an English-speaking structure was fully achieved. Québec would indeed take steps, as de Gaulle had encouraged, to become its own master, in a national sense. In November 1967, just a few months after de Gaulle's visit, René Lévesque founded the Mouvement souveraineté association, thereby launching the Québec movement for independence.

\section{The Bibliothèque nationale du Québec Is Born}

The creation of the BNQ occurred less than three weeks after de Gaulle's visit, on August 12, 1967, when the Québec Legislative Assembly unanimously passed Law 91 . Any remaining questions over what to call the Bibliothèque Saint-Sulpice (either "Bibliothèque provinciale" or "Bibliothèque d'état") in light of its new status as a government institution were thus put to rest. The government of Québec had acted decisively in establishing a national library.

The appellation "nationale" was significant and precedent setting. In granting the title Bibliothèque nationale du Québec to the Bibliothèque Saint-Sulpice, Québec legislators for the first time had affixed the term "national" to a Québec "state" ("état") institution. ${ }^{59}$ Other state institutions would follow suit. In 1968 the Legislative Assembly of Québec adopted the title of Assemblée nationale du Québec. Likewise, 
in 1970 the Provincial Archives of the Province of Québec became the Archives nationales du Québec. ${ }^{60}$

Philippe Sauvageau explained the distinct character of Québec society in relation to its national library: "Because Québec forms a distinct society in the Canadian confederation and by reason of its individual character, which centers on a cultural identity and on the French language, Québec is the only Canadian province that maintains a national library. The national library, as it turns out, is an element essential for the affirmation of this cultural identity." 61

\section{Demographic Influences}

When one looks at the demographic situation of Québec and of the French language in North America, it is not difficult to understand that the BNQ emerged because of Québec citizens' concern for preserving and transmitting their distinct French-language heritage, particularly in the face of being a minority culture in predominantly English-speaking North America.

The province of Québec is the sole province in Canada where the citizens are a French-language majority. Even though French is one of the two official languages of Canada and is the official language of Québec, French speakers across Canada (6.7 million) constitute only about 22 percent of the overall Canadian population (31.6 million). ${ }^{6}$ In contrast to the rest of Canada, native French speakers in Québec comprise approximately 83 percent of the population (approximately 5.7 million of Québec's 7.04 million inhabitants) and approximately 85 percent of the overall French-speaking population of Canada (5.7 million inhabitants in Québec out of 6.7 million French-speaking inhabitants in Canada). ${ }^{63}$

Guy Rocher has eloquently explained the Québec sentiment of fragile singularity:

Foremost is the unavoidably geographical fact: being North American. This immediately evokes a second fact: that of being a minority. North of the Rio Grande, Québec makes up but 2.5 percent of the total population that inhabits the United States and Canada. For the French speakers of Québec in particular, this demographic is particularly evocative of the singularity that exists in speaking French and in having origins steeped in French tradition in North America .... Without the existence of Québec, this culture would have neither visibility nor a significant future in North America. ... The destiny 
of this small community of French language and culture is inevitably marked by fragility, by precariousness, and consequently by the uncertainty of the future. To be a minority entails a latent, if not explicit anxiety regarding one's survival and one's collective evolution, the sentiment of what Proust calls "the permanence of danger." ${ }^{4}$

The province of Québec is thus—both literally and figuratively—the center of French language and culture in Canada and in North America. Given the demographic landscape, it is therefore logical to assume that, without a national library in Québec, the care and preservation of its unique, minority, French-language documentary heritage would remain beyond the scope of the province and thus in question. This sense of danger, the sentiment of being an endangered culture, has given added impetus to the need for a national library within Québec.

While Québec is the sole Canadian province to have established its own national library, other nations or cultural groups within nations around the world-including individual countries and/or regions within countries-have established national libraries. These institutions play a significant role in the affirmation and preservation of cultural identity and language. Countries such as Scotland and Wales, regions such as Catalonia, and cities such as Rome and Florence offer examples of national libraries that exist with distinct mandates in cultural contexts similar to that of Québec.

\section{Libraries and Literacy Shaping Memory, Shaping Society}

The founding of the BNQ in 1967 marked a noteworthy moment in the Québécois consciousness, underscoring the importance of preserving the national identity of a minority culture. Yet it would take another decade for the government to recognize the widespread need for public libraries in municipalities throughout the province "as leverage for collective economic, social, and cultural development." ${ }^{65}$ The campaign to promote reading and libraries would eventually result in a call for a national library on a grander scale-one that would be the flagship of an extensive network of libraries throughout Québec.

In 1979 the Ministry of Cultural Affairs under Denis Vaugeois issued a five-year plan-commonly referred to as the Plan Vaugeois-to encourage municipalities to work with the provincial government to develop public libraries throughout Québec. Since 1960 the proportion of the population having access to a public library had grown gradually from 45 percent to 77 percent-an increase of 1.7 percent annually. ${ }^{66}$ Yet the 
Plan Vaugeois indicated a need to "compensate for the slow progress in library development" and envisioned libraries as "both a normal complement to existing public services and the driving force of the cultural and social life of the community." 67

By expanding library buildings and collections, the ministry was also aiming to assure libraries as an appropriate point of distribution for materials published in Québec from a publishing industry that was blossoming and expanding after more than a century of religious censorship and also to rally active interest, support, and use of libraries by the general population as a means of both encouraging and enabling people to find books from Québec coming out of Québec's own literary and cultural heritage. ${ }^{68}$ The Plan Vaugeois enabled partnerships between state and municipal government for developing public libraries in municipalities where there were none and to modernize space and collections for existing libraries as well as to bring in professionally trained personnel for staffing. During the five years that the Plan Vaugeois was in effect, from 1979 to 1984, the provincial government's contributions to the development of public libraries increased by nearly 150 percent ${ }^{69}$ The percentage of the population having access to public libraries grew from 78 percent to just over 85 percent. $^{70}$

While the support of the Ministry of Cultural Affairs for public libraries fluctuated during the late 1980s and early 1990s, municipal contributions to public libraries during this same period increased significantly. ${ }^{71}$ Thus, as state contributions remained more or less stagnant, local communities began to assume a greater role in the direct responsibility for their libraries and also, as a network developed, to share resources through regional library cooperation.

\section{A Policy on Reading and Books Leads to the Call for a "grande bibliothèque"}

In the mid-1990s studies that tracked cultural activities among the population gave a bleak assessment of reading habits in Québec. In one study covering 1994, nearly 44 percent of people fifteen years of age and older admitted to never having opened a book that year. ${ }^{72}$ The Québec government took steps to intervene.

In 1998 the Ministry of Culture and Communications published the Politique de la lecture et du livre (Policy on Reading and the Book), which sparked efforts in fourteen governmental ministries and organizations to establish reading and all spheres of the book as a dominant centerpiece for cultural development in Québec. The policy was envisioned as 
a long-term plan to instill good reading habits as a common individual and social practice, omnipresent throughout Québec society. The policy stated, "We should ... guarantee the presence and emphasize the value, in public libraries, of a sufficient number of books and periodicals published in Québec in order to encourage the dissemination of the culture and literature of Québec to the population."73

The Politique de la lecture et du livre had two important outcomes for libraries. In the year following its publication the government increased subventions to public libraries by nearly 20 percent. ${ }^{74}$ Moreover, it endorsed the recommendations of the Richard Report, submitted in June 1997 by the Committee on the Development of a "grande bibliothèque." 75 This committee, chaired by Clément Richard, minister of cultural affairs from 1981 to 1985 , called for the development of a large library that would serve all of Québec.

When the government announced it would move forward on the Richard Report's recommendation to give Québec citizens "an institution of national breadth" that would be "the flagship in the network of Quebec libraries," the wheels were put into motion for legislation to make the concept of a "grande bibliothèque" a reality. ${ }^{76}$

The creation of the Richard Committee to study the prospects for a "grande bibliothèque" and the adoption of the Politique de la lecture et $d u$ livre were evidence of a remarkable new emphasis on reading and the book as a means to shape and transform Québec society. The Richard Committee, in conceptualizing the physical dimensions of a "grande bibliothèque", was also projecting the cultural and social dimensions of a "grande collection," useful and appealing to the public. As the report stated, "There is something about libraries like museums: it is first the collection that determines their strength of attraction and their social and cultural utility. Indeed, one cannot speak of a 'great' library without making reference to a 'great' collection, which is as impressive by its quantity as it is by its quality." 77

Thus, the committee weighed the importance of the collections of the $\mathrm{BNQ}$ and Montreal's central municipal library, the Bibliothèque centrale (BCM), and, taking into account the space problems at the two institutions and the potential economic advantages of a merger, concluded, "It will be necessary to unite the collections of the Bibliothèque nationale du Québec and the Bibliothèque centrale de Montréal. The members of committee believe that this is the best solution, not only because it is a means of endowing the GBQ with an initial collection impossible to constitute otherwise, but also because it is the most advantageous financially." 78 


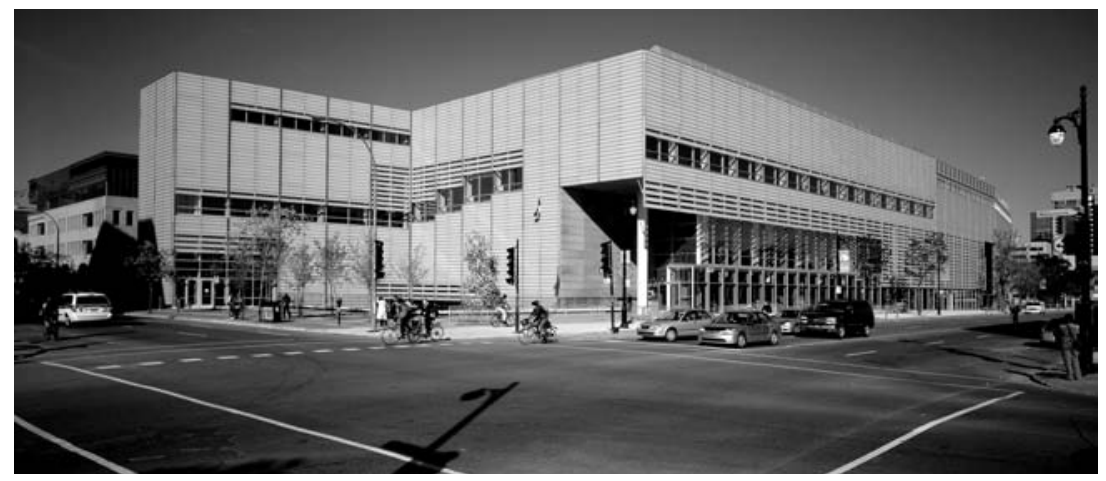

Figure 5. The Grande Bibliothèque du Québec, at the corner of Berri and Maisonneuve streets in Montréal, opened April 30, 2005. It incorporated the collections of the Bibliothèque Saint-Sulpice, then the national library of Québec, and the Bibliothèque centrale de Montréal. (C) Bibliothèque et Archives nationales du Québec, Bernard Fougères.

Soon after the Richard Report was submitted, the government appointed a provisional council to determine the needs and legislative guidelines of the project and to specify the precise relationships between the $\mathrm{BNQ}$, the Bibliothèque municipale, and what would eventually become the Grande Bibliothèque du Québec (GBQ). Public hearings were held to determine the location of the new institution. The site of the Palais du commerce in the heart of Montréal's Latin Quarter at the intersection of Berri and Maisonneuve streets was chosen. In June 1998, less than a year after the Richard Committee submitted its report, the National Assembly passed unanimously the law creating the Grande Bibliothèque, and in August Lise Bissonnette, director of the influential daily newspaper Le Devoir, was named chief operating officer. Author, journalist, and political and cultural analyst, Bissonnette had, in several editorials in Le Devoir, vigorously defended the principle of a prominent institution dedicated to the promotion of public reading. She maintained that such institutions were typical in large North American cities and that a grande bibliothèque, belonging to the citizens, was an essential cultural institution that Montréal and the province of Québec were lacking.

In January 2000 the government authorized construction of the Grande Bibliothèque. In June a team of architects was selected and agreements were reached between the Grande Bibliothèque, the $\mathrm{BNQ}$, and the city of Montréal for the transfer of collections to the GBQ. In November 2000 the Ministry of Culture and Communications put forward new legislation 
to create a new institution, merging the activities of the GBQ with the BNQ to create a new entity, described as "the new national library of Québec." The legislation was voted into law by the National Assembly in June 2001 and went into effect on March 4, 2002, at which time the GBQ and the BNQ became synonymous and plans for construction of a new building were under way. ${ }^{79}$ Bissonnette, with her proven analytical, organizational, and managerial skills, was named chief operating officer of the new institution.

By the fall of 2004 the administration had begun to move the collections from three separate library buildings-the BNQ's Saint-Sulpice and Aegidius-Fauteux libraries as well as the Bibliothèque municipale-into the new edifice. In addition, more than fifty thousand documents were moved from the collections of the Magnétothèque and the Institut Nazareth et Louis Braille (books adapted for the visually impaired in Braille, on cassette, and on compact disc), and 475,000 new acquisitions, including books and multimedia documents, were added. When the GBQ opened its doors to the public on April 30, 2005, it housed approximately 4 million documents, including 1.2 million books, 1.6 million microforms, and 1.2 million other documents (journals, newspapers, compact discs, music cassettes, DVDs, videocassettes, reference works, software, etc.), and offered a wide range of services spread out on six levels and 350,000 square feet of space. It covers every conceivable range of knowledge and culture, offering what is probably the most extensive collection of French-language documents on the North American continent.

The inauguration of the GBQ on April 30, 2005, coincided with activities for World Book and Copyright Day and the celebration of Montréal as the World Book Capital, as designated by the United Nations Educational, Scientific, and Cultural Organization (UNESCO) ${ }^{80}$ Its public opening, along with a wide range of cultural programs, activities, and expositions, represented a crowning achievement for Québec and a marked separation from the previous century-long struggle for freedom from the clergy and the right to self-determination.

Éric Bédard, historian and professor at the University of Québec at Rimouski, hailed the opening of the new library as a symbolic indicator when he wrote in Le Devoir,

In this history that is ours, this Grande Bibliothèque seems to me much more than the crowning achievement of our cultural modernity, it is also, and maybe foremost, the symbol of an ambitious re-conquest that is cultural, economical, and political all at once, 


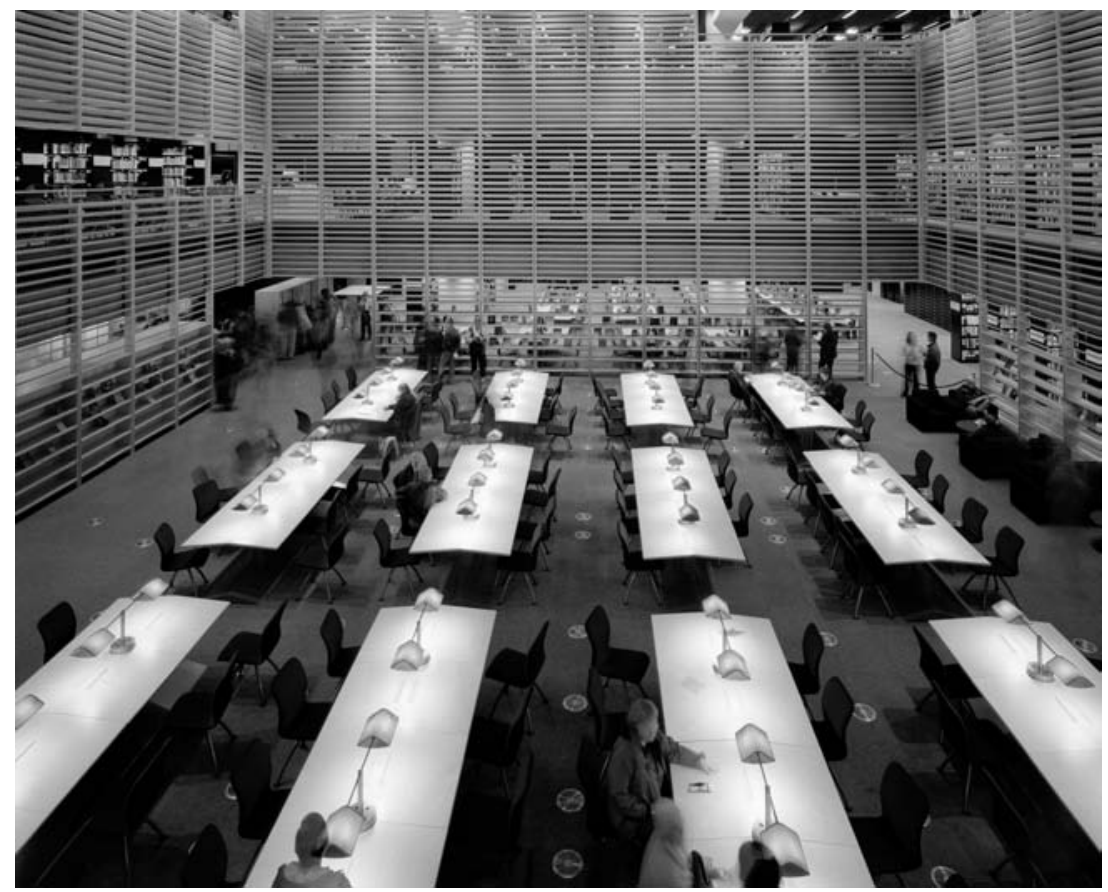

Figure 6. "The chambre de bois" (wooden room) in the Grande Bibliothèque du Québec. Multistory rows of adjustable wooden slats protect the collection, enabling conservators to allow in indirect natural light or to block it. (c) Bibliothèque et Archives nationales du Québec, Bernard Fougères.

and where the Révolution tranquille is but one indicator among others. This Grande Bibliothèque, which testifies to the spirit of resistance and to the undeniable vitality of the people of Québec, should bring us closer to our forebears. Indeed, the rich beauty of the place should recall to us the extreme impoverishment of those who, long before the Révolution tranquille, wanted to contradict the somber predictions of Lord Durham. ${ }^{81}$

Indeed, the "somber predictions of Lord Durham," who in 1839 had recommended a legislative union of Upper and Lower Canada with the aim of encouraging the extinction of French language and culture through intermingling with the more numerous English, could be put to rest by the symbolic yet very real presence of the Grande Bibliothèque and all that it represents as a cultural legacy to the French-speaking people of Québec and of Canada. 


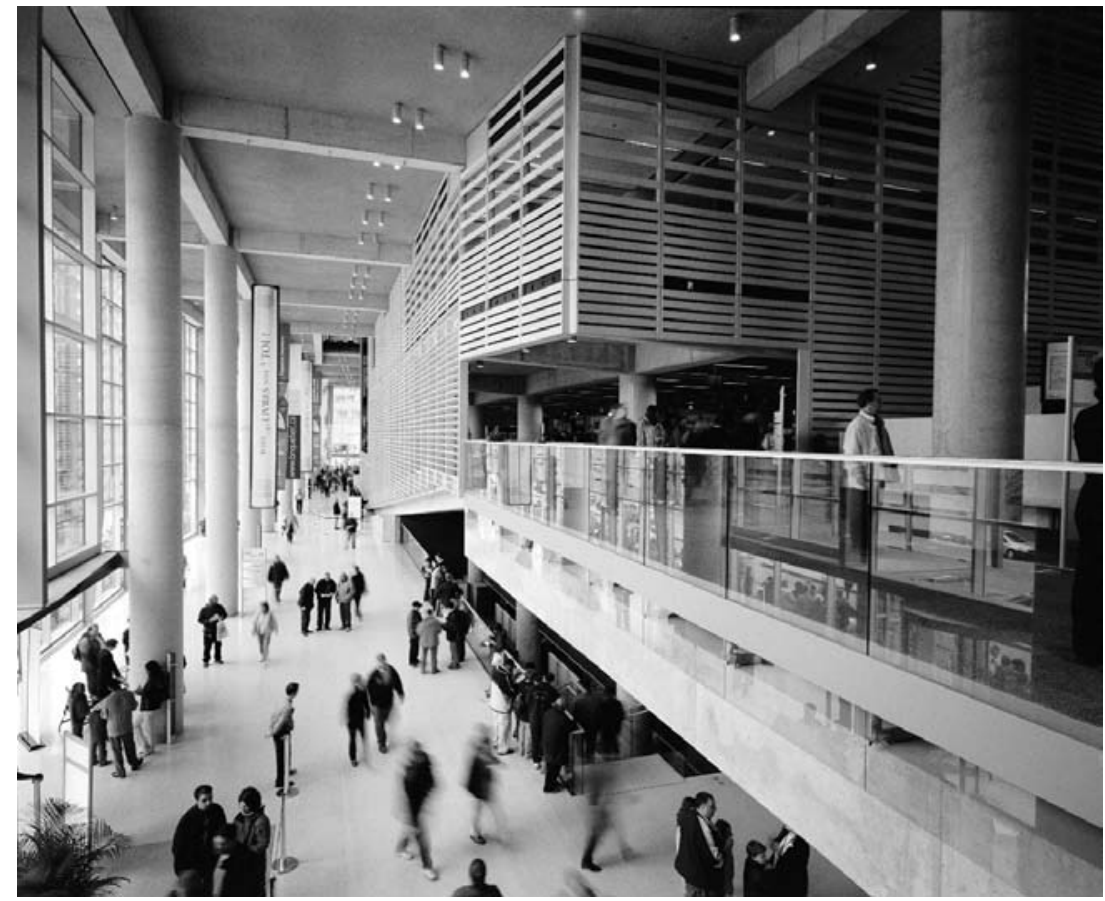

Figure 7. Main entry hall, Grande Bibliothèque du Québec, Montréal, spring 2005. (C) Bibliothèque et Archives nationales du Québec, Bernard Fougères.

\section{A Library for the Twenty-First Century: Remembering the Past, Reshaping the Present, Anticipating the Future}

The Grande Bibliothèque is a testament to the strength and fortitude of the Québécois and the French language and cultural heritage on the North American continent. The institution is infused with the sense of a legacy that pays homage to the history, culture, and memory of Québec's citizens both in its legislative mandate and in its architectural conception. The merger of the $\mathrm{BNQ}$ and the Bibliothèque centrale into the Grande Bibliothèque evokes a historical connection to each of the earlier institutions in mandating a revitalized Bibliothèque nationale, yet it goes much further by naming new missions with new tools for creating a library for the twenty-first century. The national mandate, to acquire, preserve, and disseminate the patrimonial collection, remains clear. The integration of the BCM, as a municipal library, brings a broader directive to acquire and disseminate a universal collection to the general public. 
Indeed, the two collections, now united, maintain their duality in the new building. Each is housed in one of two chambres de bois (wooden rooms), an architectural concept inspired from the title of a novel, Les chambres de bois, by renowned Québec writer Anne Hébert. ${ }^{82}$ Multistory louvered partitions made of yellow birch, the provincial tree of Québec, envelop the collections, either allowing indirect natural light or blocking it according to the conservation needs of the collection. They delineate the two collections from each other and from the reading and study areas, located on the periphery of the building. The intended effect is that when one enters the "chambre de bois," one enters into the collection, the documentary landscape of Québec.

The exterior of the postmodern six-story edifice is clad with 6,200 plates of ceramic glass specially fabricated in Québec for this project. This type of glass has never been used before in North America. Though the design is somewhat controversial, particularly since in June and July 2005 six of these glass plates shattered, it is also quite innovative in that it allows natural light to permeate the interior, filtered by the effects of the birch partitions surrounding the collections.

The main hall on the ground floor leads to the entrance, which opens into the news and new releases section, including journals, magazines, and newspapers from Québec and from around the world. The central elevators and staircase arch upward with a transparent view from the exhibition hall, at the Metro level, to the upper levels. The effect is one of vast transparency and luminosity, as though to echo the sentiment that Lise Bissonnette expressed in her inaugural address: "The book pursues the light first and foremost." ${ }^{83}$

The GBQ has been promoted as a "library for a new generation," a "place of learning," a "place with atmosphere," a "place of high culture," a "place of exchange"- a project designed to usher in a new range of collections and services for the information, educational, and cultural needs of Québec citizens in the twenty-first century. ${ }^{84}$ Indeed, with the opening of the Grande Bibliothèque, the government of Québec has come a long way in realizing the original vision as put forth in the Richard Report and in the Politique de la lecture et du livre. Yet even Lise Bissonnette in her inaugural speech on opening day referred to "an unfinished temple," "an incomplete work." ${ }^{85}$ Indeed, in the fall of 2005 a law went into effect merging the activities of the Bibliothèque nationale with those of the Archives nationales du Québec, thus creating a new institution, the Bibliothèque et Archives nationales du Québec (BAnQ) and adding the preservation and diffusion of Québec's archival and film heritage to the mandate of a new institution. ${ }^{86}$ 
The new institution's relationship to the government's Ministry of Culture and Communications marks its identity as a cultural icon for the people of Québec-a source of national identity and pride. Yet the connection to the past remains interwoven into the fabric of its presentday being. Like the Bibliothèque Saint-Sulpice and the Bibliothèque centrale de Montréal, the Grande Bibliothèque is situated in the heart of Montréal's Latin Quarter, the cultural quarter, in close proximity to the film and theater district as well as to schools and universities, notably, the Université du Québec à Montréal (UQÀM) and the Cégep du Vieux-Montréal. It is also positioned next to the central bus terminal and at the Berri-UQÀM Metro stop-a central hub in Montréal's public transportation network. In effect, in looking at a map of Montréal, one could surmise that the Grande Bibliothèque is situated between the two buildings-just two blocks east of the Bibliothèque Saint-Sulpice and a few blocks south and west of the Bibliothèque centrale.

Thus, it seems fitting that when the Grande Bibliothèque opened, the two distinguished collections of the BNQ (comprising both the Collection nationale and the original core collection from the Bibliothèque Saint-Sulpice) and the Bibliothèque municipale were merged, finally housed together with their collections accessible in one catalog, in open stacks, and in a new edifice built for the twenty-first century. It is as if, in reflecting on all the long debates of the past, they never should have been apart.

\section{The Exhibition "Tous ces livres sont à toi!" Social and Cultural Significance for Collective Memory}

To celebrate the inauguration of the Grande Bibliothèque the BNQ put together a major exhibition recalling the long and often difficult saga of the book and its close ally, the public library, in Québec. The exhibition, "Tous ces livres sont à toi!": De l'Oeuvre des bons livres à la Grande Bibliothèque (1844-2005), brought together more than 350 artifacts, including many books once labeled "forbidden," and retraced the steps of the struggle led, over the course of a century and a half, by the liberal constituents of society against the many diverse forms of control and censorship that their adversaries (often the clergy) had put into place to impede access to the printed word.$^{87}$ The title, "Tous ces livres sont à toi!" invokes the words of Aegidius Fauteux in his editorial in La Patrie on December 21, 1901, more than ten years before the advent of the Bibliothèque Saint-Sulpice. ${ }^{88}$ Fauteux described a dream that he attributed to Charles Nodier, librarian of the Arsenal Library in 
Paris, in which the librarian is escorted into a palace room glowing in the light of tall windows, where the walls are luminescent with beautiful books in magnificent bindings. ${ }^{89}$ The guide says to the poet-librarian, who is in a state of rapture, "Tous ces livres sont à toi!" (All these books are for you! $)^{90}$

The exhibition evoked the past, the early remnants of a dream that, over a 160-year evolution, led to the creation of the Bibliothèque SaintSulpice (with the two hundred thousand or so volumes that constituted its original collection), the Bibliothèque centrale de Montréal, and the slow but steady growth of a network of public libraries across Québec.

To underscore the importance of the role of libraries as well as the significance of the struggle for access to books to the development of thoughts, ideas, and knowledge in Québec society, the BNQ published with the Université Laval a catalog of the exhibition to commemorate the struggle and the legacy of a dream that has been realized in the Grande Bibliothèque. The exhibition and its catalog are thus inscribed as part of the library, as part of history, and as part of Québec's collective memory.

\section{Great Libraries and the Endurance of Cultural Memory}

From its first affirmations that French cultural heritage in North America is worth cultivating, preserving, and disseminating, to its present (re)construction as a vibrant knowledge and cultural center, the Grande Bibliothèque du Québec attests to the enduring spirit and memory of the people of Québec, encapsulated in a "great library."

This article was largely inspired by a perception of the Grande Bibliothèque as a metaphorical, almost mythical representation of any "great library"-from the papyrus scrolls of the ancient library of Alexandria, to the hallowed halls of the world's greatest national libraries, to the small public and community libraries that offer after-school reading programs to children and adolescents, crafts and book discussion groups for adults, service to shut-ins, and Internet classes for seniors. This is the ideal library that Alberto Manguel refers to in the documentary film $L a$ bibliothèque entre deux feux, "perfect because it contains only that which we wish to remember about ourselves" and perhaps because it contains only that which we wish to know.

Historians Jacques Mathieu and Jacques Lacoursière wrote, "Collective memory is society's knowledge about itself. It defines who we are in the light of who we no longer are. . . It is the point of reference through which we recognize and identify ourselves. It is self-regard in the moment, social, plural, connected to collective sensibilities. 
It sees the research of the past as a project of the present turned toward the future." 91 These same reflections can be applied to the Grande Bibliothèque. Our collective and cultural memory is reflected in the knowledge we find about ourselves in the library-in any great library. Such knowledge serves to connect us to a point of self-recognition related to the greater whole of generations that have preceded us-part of something that has endured since the beginning of recorded history and will continue to endure as part of some future legacy.

\section{Notes}

I would like to thank André Senécal, professor of French and Canadian studies at the University of Vermont, Réjean Savard, professor at the École de bibliothéconomie et des sciences de l'information, Université de Montréal, and Jean-René Lassonde, reference librarian extraordinaire at the Bibliothèque et Archives nationales du Québec, for their precious aid and guidance during the course of this research project. Text translations from French to English are mine.

1. According to Marcel Lajeunesse, "La lecture publique à Montréal de 1900 à 1960 ou les bonnes lectures dans une métropole industrielle," Documentation et Bibliothèques 41, no. 3 (1995): 147.

2. Whitey North Seymour, Jr., and Elizabeth N. Layne, For the People: Fighting for Public Libraries (Garden City, N.Y.: Doubleday, 1979), 11.

3. Durand R. Miller, comp., Carnegie Grants for Library Buildings, 1890-1917: A List of Library Buildings, Public and Academic, Erected with Funds Provided by Andrew Carnegie and Carnegie Corporation of New York (New York: Carnegie Corporation, 1943), 8.

4. For a broad perspective on the extent of the debate see Kenneth Landry, "La lecture publique au Québec à l'aube du XXe siècle: Les obstacles à la création de la bibliothèque civique de Montréal," Les bibliothèques québécoises d'hier à aujourd'hui: Actes du colloque de l'ASTED et de l'AQÉI, Trois-Rivières, 27 octobre 1997, ed. Gilles Gallichan, Collection Documentation et bibliothèques, no. 2 (Montréal: Éditions ASTED, 1998), 67-78; Marcel Lajeunesse, "Les bibliothèques publiques à Montréal au début du XXe siècle: Essai d'histoire socio-culturelle," Readings in Canadian Library History 2, ed. Peter F. McNally (Ottawa, Ontario: Canadian Library Association, 1996), 173-98; Réjean Savard, "Le discours sur la lecture et l'évolution des bibliothèques publiques au Québec de 1850 à 1950," Argus 26, no. 2 (1997): 19-27; Michèle Dagenais, "Vie culturelle et pouvoirs publics locaux: La fondation de la bibliothèque municipale de Montréal," Urban History Review 24, no. 2 (1996): 40-57; Gilles Gallichan, "Les bibliothèques entre censure et culture," Cap-aux-Diamants, no. 63 (Fall 2000): 28-33.

5. Lajeunesse, "Bibliothèques publiques," 173; Savard, "Discours," 20-21.

6. Landry, "La lecture publique," 69.

7. Marcel Lajeunesse, "Les bibliothèques paroissiales, précurseurs des bibliothèques publiques au Québec?” in Gallichan, Les bibliothèques québécoises, 43.

8. Bibliothèque de la paroisse Sainte-Anne, Règlements et catalogue, 1898, quoted in Savard, "Discours," 20-21. 
9. Dagenais, "Vie culturelle," 43.

10. Ibid., 45-46; Savard, "Discours," 22.

11. La Vérité, June 21, 1902, quoted in Savard, "Discours," 22.

12. "Les bibliothèques Carnegie," in La Vérité, June 21, 1902, 3, quoted in Dagenais, "Vie culturelle," 45.

13. Aegidius Fauteux [M. France, pseud.], "Les bibliothèques publiques," La Patrie, December 21, 1901, 24.

14. Ibid. See also comments by Marcel Lajeunesse in Les Sulpiciens et la vie culturelle à Montréal au XIXe siècle (Montréal: Ides, 1982), 202.

15. Jean-René Lassonde, La Bibliothèque Saint-Sulpice, 1910-1931, 3rd ed. (Montréal: Bibliothèque nationale du Québec, 2001), 39, notes that Fauteux was a student of the Sulpicians, first at the Collège de Montréal, then as a theology student at the Grand Séminaire. He later studied law at the Université Laval de Montréal and was admitted to the bar in 1903, although he never practiced law. Instead, he pursued a career in journalism before being named conservator of the Bibliothèque Saint-Sulpice.

16. Dagenais, "Vie culturelle," 46.

17. Lajeunesse, Les Sulpiciens, 208-9; Dagenais, "Vie culturelle," 46.

18. Dagenais, "Vie culturelle," 46; Montréal (Québec), BM60, Fonds de la Bibliothèque de la Ville de Montréal, 1903-80, "Histoire administrative," http:/ /www2.ville.montreal.qc.ca/archives/guide/Bm060.htm (accessed June 7, 2005).

19. Aegidius Fauteux, “'Règlement d'une bibliothèque catholique.' Extrait d'une conférence de M. Aegidius Fauteux . .." in Elie-J. Auclair, "Chronique des revues," La Revue Canadienne, n.s. 16 (July-December 1915): 550-55, quoted in Lajeunesse, "Bibliothèques publiques," 186.

20. Fauteux quoted in Lassonde, La Bibliothèque Saint-Sulpice, 203.

21. Handwritten notes contained in "Essai de Classification décimale Dewey refondu par Aegidius Fauteux," Fonds Saint-Sulpice, BNQ, quoted in Lassonde, La Bibliothèque Saint-Sulpice, 204.

22. Fauteux, "Règlement d'une bibliothèque catholique," 553, quoted in Lassonde, La Bibliothèque Saint-Sulpice, 204.

23. Ibid., 204.

24. Letters from Aegidius Fauteux to Abbot Léonidas Perrin, October 22, 1915, and February 24, 1916, both in Fonds Saint-Sulpice, BNQ, quoted in Lassonde, La Bibliothèque Saint-Sulpice, 203.

25. Letter from Abbot Léonidas Perrin to Aegidius Fauteux, April 3, 1916, Fonds Saint-Sulpice, BNQ quoted in Lassonde, La Bibliothèque Saint-Sulpice, 203.

26. Montréal (Québec), Division de la gestion des document et des archives (DGDA), "Procès verbaux du Conseil municipal," microfilm, bobine 21, August 6, 1902, quoted in Dagenais, "Vie culturelle," 46.

27. Ibid.; Règlement no. 291, "Règlement concernant l'établissement et l'entretien d'une bibliothèque publique et gratuite," quoted in Dagenais, "Vie culturelle," 46.

28. Dagenais, "Vie culturelle," 47, explains that the municipal library's gradual shift in vocation from a strictly technical library to more of a true public library was probably due in no small measure to the presence of its first librarian, Éva Circé-Coté, who was also a journalist and defender of education, democracy, and the rights of women and the working class. She wrote under a masculine 
pseudonym, Julien Saint-Michel, notably for Le Monde Ouvrier-the official publication of the Québec Federation of Workers.

29. Archives de l'Archevêché de Montréal (AAM), dossier 759, 112, Paul Bruchési aux membres du Comité de la Bibliothèque civique, February 18, 1907, quoted in Dagenais, "Vie culturelle," 47.

30. Montréal (Québec), Division de la gestion des documents et des archives (DGDA), "Procès verbaux de la Commission de l'hôtel de ville," microfilm, bobine 1, March 7, 1907, quoted in Dagenais, "Vie culturelle," 47.

31. This system of notation was illustrated at the centenary exhibition of the Bibliothèque centrale de Montréal, "100 ans d'histoire à voir: La Bibliothèque centrale de Montréal/100 Years of History: The Municipal Library of Montreal," from June 2 to November 28, 2004, Jean-François Chartrand, curator.

32. For more information see Paul Michaud, Au temps de l'Index (Montréal: Libre Expression, 1996) and Daniel Gagnon, "Libre opinion: Le génie de Gérard Bessette," Le Devoir, March 3, 2005, A6.

33. Lajeunesse, "Bibliothèques publiques," 191-92.

34. Lassonde gives the date of closure to the general public as July 31, 1931 (La Bibliothèque Saint-Sulpice, 310). He recounts in some detail the difficulties leading to the closure in chapter 6, "Des difficultés à la fermature," 289-325.

35. Letter from Fauteux to Abbot Neveu, superior of the seminary, February 4, 1932, Archives of the Séminaire de Saint-Sulpice de Montréal, section 35, carton 158, chemise 4, quoted in Lassonde, La Bibliothèque Saint-Sulpice, 316.

36. Lassonde, La Bibliothèque Saint-Sulpice, 316; Montréal (Québec), BM60, Fonds de la Bibliothèque de la Ville de Montréal, 1903-80, "Note générale: Liste des bibliothécaires de la Bibliothèque de la Ville de Montréal," http://www2. ville.montreal.qc.ca/archives/guide/Bm060.htm (accessed June 10, 2005).

37. Roland Auger, "La Bibliothèque nationale du Québec," in Livre, bibliothèque et culture québécoise: Mélanges offerts à Edmond Desrochers, S.J., ed. Georges-A. Chartrand (Montréal: ASTED, 1977), 622; "L'ÉBSI: Son histoire, sa mission," http://www.ebsi.umontreal.ca/diffu/mission.htm (accessed April 24, 2006).

38. René Garneau, "Inventaire de la bibliothèque Saint-Sulpice, 1939," report addressed to the Hon. Oscar Drouin, ministre du Commerce et de l'Industrie du Québec, June 24, 1940, quoted in Lassonde, La Bibliothèque Saint-Sulpice, 320-21.

39. Lassonde, La Bibliothèque Saint-Sulpice, 319-20.

40. Jean-Remi Brault, Regard sur l'évolution des bibliothèques québécoises: Récit d'un itinéraire professionnel (Montréal: Éditions ASTED, 2004), 113, 114.

41. Auger, "La Bibliothèque nationale du Québec," 624.

42. Guy Frégault, Chronique des années perdues (Montréal: Leméac, 1976), 137.

43. Direction de la Bibliothèque Saint-Sulpice, "La Bibliothèque Saint-Sulpice entre le passé et l'avenir," Bulletin de l'Association Canadienne des Bibliothécaires de Langue Française 12, no. 2 (1966): 78. According to the article, the number of employees went from twenty-four in 1964 to sixty-four in 1966 and included recruitment of professional librarians.

44. Québec (Province), Ministère des affaires culturelles, "Un foyer de culture vivante," Culture Vivante, no. 2 (1966): 49.

45. Georges Cartier, "Le Comité d'études sur la bibliothèque provinciale," Bulletin de l'Association Canadienne des Bibliothécaires de Langue Française 11, no. 3 (1965): 108-11.

46. Auger, "La Bibliothèque nationale du Québec," 626. 
47. Cartier, "Le Comité," 109, 111.

48. Ibid., 109-10.

49. The Commission royale d'enquête sur l'enseignement dans la province de Québec was established in the early 1960s to reform and modernize Québec's educational system. The commission's findings, published in five volumes between 1963 and 1966, played a significant role in educational and social reforms for years to come. Auger, "La Bibliothèque nationale du Québec," 626; Jean-Remi Brault, "La Bibliothèque nationale du Québec," in Gallichan, Les bibliothèques québécoises, 32.

50. Frégault, Chronique des années perdues, 163.

51. "Mémoire du conservateur," October 6, 1965, quoted in Roland Auger, "L'annexe Aegidius Fauteux de la Bibliothèque Saint-Sulpice," Bulletin de l'Association Canadienne des Bibliothécaires de Langue Française 13, no. 1 (1967): 8.

52. Auger, "L'annexe Aegidius Fauteux," 8.

53. Direction de la Bibliothèque Saint-Sulpice, "La Bibliothèque SaintSulpice," 79.

54. Auger, "L'annexe Aegidius Fauteux," 10-11.

55. Auger, "La Bibliothèque nationale du Québec," 627.

56. Jean Lesage is quoted in Bilan du siècle, s.v. "24 mars 1961—Création du ministère des Affaires culturelles du Québec," http://bilan.usherbrooke. ca/bilan/pages/evenements/1420.html (accessed June 15, 2005).

57. In "La personalité de de Gaulle et ses relations avec le Québec: Résumé des discours des 23 au 26 juillet 1967," Le Franco Folio, special ed. (April 2005), http://recit-us.cspi.qc.ca/histoire/2004-2005/equip51/resumediscours.htm (accessed July 27, 2007). These citations are supported with scanned images of articles and photographs from newspapers during this period, including $L e$ Journal de Montréal, http://recit-us.cspi.qc.ca/histoire/2004-2005/equip51/ pageunejml.htm, and Le Monde, http:/ / recit-us.cspi.qc.ca/histoire/2004-2005/ equip51/pageunemonde1.htm (accessed July 27, 2007).

58. There are numerous Internet sites that document de Gaulle's visit to Québec in 1967, including Fondation et l'Institut Charles de Gaulle, "De Gaulle et le Québec," http:/ / www.charles-de-gaulle.org/article.php3?id_article=111; Archives-télé de Radio-Canada, "Vive le Québec libre!" http:/ /archives.radio-canada.ca/400d .asp?id=0-17-209-1048-20\&wm6=1; and Wikipédia: L'encyclopédie libre, s.v. "Charles de Gaulle: Affaire du Québec Libre," http://fr.wikipedia.org/wiki/Charles_de_ Gaulle\#Affaire_du_.22Qu.C3.A9bec Libre.22 (all accessed March 21, 2006).

59. Auger, "La Bibliothèque nationale du Québec," 627; Lajeunesse, "Au service de la mémoire des Québécois," 14.

60. In 1987, twenty years after the founding of the BNQ, the Meech Lake Accord introduced constitutional reforms to recognize Québec's status as a distinct society.

61. Philippe Sauvageau, "La Bibliothèque nationale du Québec," Bulletin des Bibliothèques de France 43, no. 4 (1998): 36.

62. On July 31, 1974, the Québec National Assembly passed the "Loi sur la langue officielle" (Law on the Official Language), recognizing French as the official language of Québec. The Charter of the French Language followed in 1977, making "French the language of government and the law, as well as the normal and everyday language of work, instruction, communication, commerce and business." See Québec (Province), Ministère des relations internationales, 
"Le français, langue officielle au Québec depuis 25 ans," Communiqués de presse, Québec, July 30, 1999, http://www.mri.gouv.qc.ca/fr/salle_de_presse/archives/ communiques/textes/1999/1999_07_30.asp; and Québec (Province), Charter of the French Language, 1977, http:/ / www.olf.gouv.qc.ca/english/charter/preamble. html (both accessed April 24, 2006); Canada, Statistics Canada, "Population estimate" [from 2001 census], http:/ / www.statcan.ca/start.html, and "Population by mother tongue by provinces and territories" [from 2001 census], http:/ /www .statcan.ca/english/Pgdb/demo11b.htm (accessed March 1, 2006).

63. Atlas de la francophonie, http://franco.ca/atlas/francophonie/english/ impre.cfm? Id=9 (accessed April 17, 2006).

64. Guy Rocher, "Le statut culturel du français au Québec: État de la question," in Le statut culturel du français au Québec, ed. Michel Amyot ([Québec]: Conseil de la langue française, ca. 1984), 15-16. Also available online: http:/ /www.cslf .gouv.qc.ca/Publications/PubF112/F112.html\#2 (accessed April 24, 2006).

65. "[L]a bibliothèque constitue un des plus puissants leviers du développement économique, social et culturel d'une collectivité,” in Québec (Province), Ministère des affaires culturelles, Une bibliothèque dans votre municipalité (Québec: Ministère des affaires culturelles, 1979), 9.

66. Baillargeon, "Les bibliothèques publiques et la Révolution tranquille au Québec," 8.

67. Québec (Province), Ministère des affaires culturelles, Une bibliothèque dans votre municipalité, 33.

68. Baillargeon, "Les bibliothèques publiques et la Révolution tranquille au Québec," 8, notes that the book market in Québec, at the dawn of the Révolution tranquille, was dominated by the foreign press (principally from France), that bookstores were rare and often of mediocre quality, and that the Québec book trade was at a disadvantage in relation to the distribution of imported books. Denis Vaugeois would later write, "Any plan to encourage the creation of books ... can give no tangible result if the book has no means of reaching the public. The objective was not so much to assure a supply of authors and published works, but rather to see that the works of these authors, the books of these publishers could easily be joined with the public" ("Du Plan Vaugeois à aujourd'hui," Bibliothèques publiques et transmission de la culture à l'orée du XXe siècle d'hier à aujourd'hui, ed. Jean-Paul Baillargeon [Sainte-Foy: Éditions de l'IQRC: Presses de l'Université Laval; Montréal: Éditions de l'Asted, 2004], 83).

69. Réjean Savard, "L'évolution des bibliothèques publiques au Québec de 1960 à 1995," in Gallichan, Les bibliothèques québécoises, 144.

70. Commission d'étude sur les bibliothèques publiques du Québec, Les bibliothèques publiques, une responsabilité à partager: Rapport de la Commission d'étude sur les bibliothèques publiques du Québec ([Québec]: La Commission, 1987), 22.

71. Savard, "L'évolution," 143 (table), 145 (table), 148 (table). Municipal contributions increased by nearly 75 percent between 1988 and 1995 .

72. Rosaire Garon and Louise Santerre, Déchiffrer la culture au Québec (Québec: Les Publications du Québec, 2004), 123, 127, quoted in Baillargeon, "Les bibliothèques publiques et la Révolution tranquille au Québec," 9.

73. The Ministère des affaires culturelles changed its name to the Ministère de la culture in 1993 and to the Ministère de la culture et des communications-its present-day appellation-in 1994. Québec (Province), Le temps de lire, un art de vivre: Politique de la lecture et du livre (Québec: Ministère de la culture 
et des communications, 1998), 33.

74. Québec (Province), Bibliothèques publiques: Statistiques 1999 (Québec: Ministère de la culture et des communications, 2002), 11.

75. Québec (Province), Comité sur le développement d'une très grande bibliothèque, Une grande bibliothèque pour le Québec: Rapport (Québec: Ministère de la culture et des communications, 1997).

76. Québec (Province), Le temps de lire, 42, 44.

77. Québec (Province), Comité sur le développement d'une très grande bibliothèque, Une grande bibliothèque pour le Québec, 49.

78. Ibid.

79. Bibliothèque nationale du Québec, Rapport annuel, 2001/2002 (Montréal: La Bibliothèque, 2002), [5], 7. The construction project for the GBQ broke ground in July 2001. See Bibliothèque nationale du Québec, "Construction de la GB,” http://www.banq.qc.ca/portal/dt/a_propos_banq/qui_sommes-nous/ historique/qsn_historique.jsp (accessed June 5, 2006).

80. Montréal (Québec), Montréal World Book Capital 2005/2006, “About.” http://mcml.canoe.com/en/abouttheevent.html (accessed May 5, 2006).

81. Éric Bédard, "La Grande Bibliothèque-Un témoignage de notre résistance," Le Devoir, May 11, 2005, http://www.ledevoir.com/2005/05/11/81471 .html?217 (accessed June 2, 2006). The Lord Durham reference is to John George Lambton, earl of Durham (1792-1840), who was colonial administrator, governor general, and high commissioner of British North America, sent to Canada to investigate the situation in the wake of the Rebellion of 1837-38. His assessment is chronicled in the Report on the Affairs of British North America (1839).

82. Anne Hébert, Les chambres de bois (Paris: EÏditions du Seuil, 1958), translated by Katherin Mezei as The Silent Rooms (Toronto: Musson Book Co., ca. 1974). Much of the description of collections and resources is derived from Bibliothèque nationale du Québec, Voici votre Grande Bibliothèque (Montréal: Bibliothèque nationale du Québec, 2005), 6-16.

83. Lise Bissonnette, "Allocution à l'occasion de l'inauguration de la Grande Bibliothèque,” April 29, 2005, http://www.banq.qc.ca/portal/dt/a_propos_banq/ qui_sommes-nous/discours_allocutions/all_ouverture_gb.jsp (accessed June 5, 2006).

84. Bibliothèque nationale du Québec, "Présentation générale," http:/ / www .bnquebec.ca/fr/edifice/edif_present_gen.htm (accessed December 4, 2003; this site was no longer accessible in August 2005).

85. Bissonnette, "Allocution."

86. Québec (Province), Ministère de la culture et des communications, "L'Assemblée nationale adopte le projet de loi 69 modifiant la Loi sur la Bibliothèque nationale du Québec, la Loi sur les archives et d'autres dispositions législatives,” December 10, 2004, http://www.banq.qc.ca/portal/dt/a_propos_banq/ communiques/archives/com_2004_12_102.jsp (accessed June 6, 2006). This new model bears a resemblance to the federal model, Bibliothèque et Archives du Canada (Library and Archives of Canada), which, when passed in April 2004, merged the activities of the National Library and National Archives of Canada into a new institution. See Bill C-8, The Library and Archives of Canada Act, 3rd sess., 37th Parliament, 2004 (assented to April 22, 2004), Statutes of Canada, 2004, c. 11, http:/ /www.parl. gc.ca/common/bills_ls.asp?lang=E\&ls=c8\&source=library_prb\&Parl=37\&Ses=3 (accessed June 5, 2006). 
87. The exhibition catalog is entitled "Tous ces livres sont à toi!": De l'oeuvre des bons livres à la Grande Bibliothèque (1844-2005): Catalogue de l'exposition inaugurale de la Grande Bibliothèque de la Bibliothèque nationale du Québec présentée du 29 avril 2005 au 31 janvier 2006 (Montréal: Bibliothèque nationale du Québec; Québec: Presses de l'Université Laval, 2005).

88. Fauteux, "Les bibliothèques publiques," 24.

89. The Bibliothèque de l'Arsenal is currently a branch of the Bibliothèque nationale de France. In Nodier's time (1780-1844) it was the library of the comte d'Artois.

90. This dream is largely translated from Fauteux, "Les bibliothèques publiques," 24.

91. Jacques Mathieu and Jacques Lacoursière, Les mémoires québécoises (SainteFoy, Québec: Les Presses de l’Université Laval, 1991), 20. 